\title{
Salience of initial attitude, magnitude of incentive, and attitude change in a forced compliance paradigm
}

\author{
JOHN C. TOUHEY \\ University of California, Santa Cruz, California 95064
}

\begin{abstract}
To examine the application of interpersonal simulation findings to cognitive dissonance and incentive theories of attitude change in the forced compliance paradigm, 60 Ss were paid 50 cents or $\$ 2.50$ to write counterattitudinal essays with salient or nonsalient initial attitudes. Findings showed that the larger incentive yielded greater change for salient pretest attitudes but that the smaller incentive led to more change of nonsalient pretest attitudes. Measures of error in attitude recall and a correlational analysis between pretest, posttest, and recalled attitudes were also consistent with Bem's (1967) hypothesis of isomorphism between the attributions of Ss and observers. It is proposed that remaining simulation data reported in the cognitive dissonance/self-perception controversy may identify additional parameters of attitude changes in forced compliance experiments.
\end{abstract}

When a $\mathrm{S}$ is induced to engage in a behavior that is contrary to his private beliefs, a state of cognitive dissonance ensues. To the extent that the $S$ attributes insufficient justification, high choice, or freedom from situational constraint to his counterattitudinal act, dissonance is increased, and his attitudes change in a direction consistent with his behavior.

These two propositions entail, perhaps, the most controversial single prediction derived from dissonance theory: that Ss who receive smaller incentives for engaging in a counterattitudinal act will show more attitude change than $S$ s who perform the same act for larger incentives (Festinger \& Carlsmith, 1959; Festinger, 1957). Since Festinger and Carlsmith's demonstration of an inverse or negative relationship between the magnitude of incentive and attitude change over 30 studies (reviewed by Collins \& Hoyt, 1972) have attempted to replicate, extend, infirm, or examine the parameters of the finding, and four somewhat different approaches may be identified.

First, a number of early studies (e.g., Brehm \& Cohen, 1962) reported negative relationships between the magnitude of incentive and attitude change in experiments designed to extend Festinger and Carlsmith's findings over a variety of attitude issues, compliance behaviors, and other closely related experimental procedures. On the other hand, a second approach advanced by Rosenberg (1965), Elms and Janis (1965), and Janis and Gilmore (1965) has proposed that a direct or positive relationship between the magnitude of incentive and attitude change will be obtained when the Ss' suspicions of unduly large financial inducements and other evaluation artifacts are removed from the forced compliance experiment. In contrast to the early dissonance researchers, who were not much concerned

The present study was supported in part by a research fellowship (1F22 MH02264-01) from the Public Health Service of the United States Department of Health, Education, and Welfare to specify theoretical mechanisms mediating between payment and attitude change, the incentive theorists have suggested that larger incentives lead Ss to more biased scanning than do smaller incentives and that increased contact with opposing arguments will yield the most change.

A third and more recent trend in the dissonance-incentive theory controversy has sought to specify the limiting conditions of positive and negative relationships between incentives and attitude changes and, when possible, to establish both findings within the same experiment (e.g., Carlsmith, Collins, \& Helmreich, 1966; Linder, Cooper, \& Jones, 1967). In this effort to attain theoretical integration of the opposing predictions, a number of variables have been established as parameters of the two hypotheses. In addition to Carlsmith, Collins, and Helmreich's finding that role playing yielded dissonance effects and essay writing yielded incentive effects, Linder, Cooper, and Jones (1967) and Sherman (1970) have reported that increasing the Ss' perception of choice to commit counterattitudinal behavior yields dissonance outcomes but that decreased perceptions of choice confirm the incentive theory prediction of a positive relationship between incentive and attitude change. Additional variables that have been explored include the persuasibility of the audience that will hear the counterattitudinal communication (Nel, Helmreich, \& Aronson, 1969), the timing of the payment (Rossomando \& Weiss, 1970), the time intervening between the act of compliance and the measurement of the postmanipulation attitudes (Crano \& Messe, 1970), and Ss observing videotape recordings of their counteradvocacies (Helmreich \& Collins, 1968).

Finally, the large number of replication failures in a most recent series of studies reported by Collins and his associates (Collins, Ashmore, Hornbeck, \& Whitney, 1970; Collins \& Helmreich, 1970) has questioned the 
reliability of any standardized forced compliance procedures for consistently obtaining the dissonance predicted negative relationship between the magnitude of incentive and attitude change. Indeed, several classic dissonance studies (e.g., Festinger \& Carlsmith, 1959; Cohen. 1962) have failed to be replicated by Collins, raising the possibility that the prediction may not generalize across different attitude issues, experimenters, and other minor variations in the forced compliance procedures

The present study approaches the dissonance and incentive theory predictions from the perspective of Bem's self-perception theory (Bem, 1965, 1967; Bem \& McConnell, 1970) and the additional simulation data gathered by the critics of the self-perception theory (Jones, Linder. Kiesler, Zanna, \& Brehm, 1968; Piliavin, Piliavin, Lowenton, McCauley, \& Hammond, 1969). Although Bem and McConnell's demonstration that Ss in a forced compliance experiment do not recall their initial attirudes appears to have verified the self-perception theory in the context of simulation methodology, the original controversy concerning the information provided to observers (Jones et al, 1968; Bem. 1968) suggests that variations in the salience of initial attitudes might differentiate between the dissonance and incentive theory predictions. Specifically, Jones et al obtained positive relationships between the magnitude of incentive and attitude change when their observers were given information concerning the initial attitudes of the Ss. Thus, Bem's hypothesis of isomorphism between the attributions of actors and observers would predict that highly salient initial attitudes entail a positive relationship between incentive and attitude change for Ss who actually participate in the forced compliance experiment. On the other hand, the self-perception theory, and particularly the Piliavin et al simulation data, indicate that the dissonance predicted negative relationship between incentive and attitude change might be expected when Ss are unable to recall their premanipulation attitudes.

One way of examining the role of initial attitudinal salience as a differentiating parameter of the opposing dissonance and incentive theory predictions would require that one group of experimental $S s$ engage in a counterattitudinal behavior after their initial attitudes have been made highly salient while a second group of Ss enact the same behavior with the perception that their initial attitudes are already consistent with the direction of their counteradvocacy. Therefore, one group of Ss was told that their initial attitudes were extremely unfavorable to the attitude issue immediately before they wrote a counterattitudinal essay, and a second group of Ss was led to believe that their initial attitudes were already quite favorable to the position that they were about to advocate. Two levels of incentive were then orthogonally varied across the salience manipulation in order to examine the relationship between the reiteration of misattribution of initial attitudes and magnitude of incentive as determinants of attitude change.

\section{METHOD}

The Ss were 76 undergraduates enrolled in introductory psychology classes at the University of Tulsa. All Ss received participation credits which counted toward their final grade in the course. One week before the experimental sessions, Ss filled out at titude questionnaires for a variety of national, local, and campus issues. The attitude on which there was most consensus among Ss was selected for further study: "Students living on campus should have unrestricted visiting privileges." Responses were obtained on a 61-point horizontal scale labeled at 10-point intervals from 0 ("strongly disagree") to 30 ("neither agree or disagree") through 60 ("strongly agree"). Since the forced compliance paradigm requires Ss to write essays against their initial attitudes, a small number of Ss whose initial attitudes fell below the midpoint of the scale were eliminated from the study. Ss were then randomly assigned to the four experimental conditions: (1) $\$ 2.50$ incentive, salient initial attitude; (2) 50-cent incentive, salient initial a ttitude; (3) $\$ 2.50$ incentive, misat tributed initial attitude; and (4) 50-cent incentive, misattributed initial attitude. One control condition was run in order to detect any extraneous sources of at titude change during the time intervening between the pretesting and the experimental sessions.

The experiment was conducted 7-10 days after the pretesting. Ss were run in groups of four to six, and all Ss were told that the Department of Psychology was collecting arguments for and against unrestricted visiting privileges for students living on campus. At this point, Ss assigned to the two initially salient attitude conditions were told: "We brought you four (five or six) people together today for a group discussion on the pros and cons of unrestricted visiting privileges for students living at the University of Tulsa. Of course, we realize that all of you hold very definite and favorable attitudes toward open visitation. But it usually helps the group discussion to think of as many good arguments as possible against open visitation. This way the group can clearly understand the negative side of the issue even though each of you is personally very strongly in favor of unrestricted visiting privileges. So I'd like each of you to write an essay that argues against open visitation even though you are really in favor of it. I can pay you 50 cents $(\$ 2.50)$ for thinking of some good arguments against unrestricted visiting privileges and writing them down. Okay. Will you do it"?

Ss in the two salient initial attitude conditions were then paid 50 cents or $\$ 2.50$ and signed a receipt which reiterated the salience manipulation: "I acknowledge receipt of payment of 50 cents $(\$ 2.50)$ for writing an essay opposed to open visitation even though I am strongly in favor of this policy."

Ss assigned to the two initially misattributed attitude conditions were read somewhat different instructions: "We brought you four (five or six) people together today for a group discussion on the pros and cons of unrestricted visiting privileges for students living at the University of Tulsa. Of course, we realize that each of you expressed serious reservations about open visitation on those attitude questionnaires last week. In fact, we selected the four (five or six) of you especially for this discussion because your attitudes toward open visitation were among the least favorable in the entire class. Nearly everyone else in the class, except for your four (five or six) people was very much in favor of unrestricted visiting privileges. It usually helps the group discussion to think of as many good arguments as possible against open visitation. This way the group can clearly understand the negative side of the issue by thinking of good arguments that support your opposition to open visitation. So I'd like each of you to write an essay that argues against open visitation, since your attitudes are not very favorable. I can pay you 50 cents $(\$ 2.50)$ for thinking of some good arguments 
against unrestricted visiting privileges and writing them down. Okay. Will you do it"?

$\mathrm{Ss}$ in the two misattributed initial attitude conditions were then paid 50 cents or $\$ 2.50$ and signed a receipt which reiterated the misattribution manipulation: "I acknowledge receipt of payment of 50 cents $(\$ 2.50)$ for writing an essay opposed to open visitation and I am personally against this policy."

When the essays had been completed, all experimental Ss were asked to fill out an attitude scale on open visitation that was identical to the measure administered during the preceding week. Finally, Ss were asked to recall their attitudes toward open visitation at the earlier pretesting session on a second copy of the attitude scale. Ss in all experimental conditions were then debriefed and cautioned not to discuss the experiment with others until the end of the week.

Control Ss in the present study were run in one group session. Their only task was to fill out the same attitude questionnaire that had been administered the preceding week and recall their initial at titudes on a second copy of the questionnaire.

\section{RESULTS}

For the four experimental conditions and the control group, initial attitudes toward open visitation ranged between 50 ("agree") and 60 ("strongly agree"), with an overall mean of 52.3. A one-way analysis of variance $(F=.26, d f=4 / 70)$ indicated that the five groups held similar initial attitudes toward open visitation. ${ }^{1}$ Table 1 shows the mean attitude change as a function of magnitude of incentive and salience of initial attitude. As seen in Column 1 of Table 1 , the $\$ 2.50$ payment yields more attitude change against unrestricted visitation than the 50-cent payment when the initial attitudes are salient. However, Ss who are led to believe that they initially opposed open visitation show the effect predicted by dissonance theory: a payment of 50 cents yielding more attitude change than the $\$ 2.50$ payment. Control Ss show virtually no change.

Results of a 2 by 2 analysis of variance $(\$ 2.50$ incentive vs 50 -cent incentive by salient initial attitude vs misattributed initial attitude) on the change scores confirms the trends shown in Table 1 . There was a very small main effect $(F=3.42$, df $=1 / 56, p<.10)$ for salience, indicating that $S s$ in the two misattribution conditions showed slightly more change against unrestricted visitation than Ss who wrote against initially salient attitudes. The main effect for incentive was not significant and the interaction $(F=5.98, \mathrm{df}=1 / 56$,

Table 1

Mean Attitude Change as a Function of Magnitude of Incentive and Salience of Initial Attitude

\begin{tabular}{clcc}
\hline Incentive & \multicolumn{1}{c}{$\begin{array}{c}\text { Initial } \\
\text { Attitude }\end{array}$} & $\begin{array}{c}\text { Attitude } \\
\text { Change }\end{array}$ & $\begin{array}{c}\text { Attitude } \\
\text { Recall } \\
\text { Error }\end{array}$ \\
\hline$\$ 2.50$ & Salient & -9.7 & 1.1 \\
$\$ .50$ & Salient & -3.8 & .7 \\
$\$ 2.50$ & Misattributed & -5.7 & 7.3 \\
$\$ .50$ & Misattributed & -11.5 & 9.9 \\
Control & & 1.2 & .4 \\
\hline
\end{tabular}

Note-Negative numbers indicate changes against open visitation.
Table 2

Correlations Between Recall of Initial Attitudes and Initial and Final Attitudes

\begin{tabular}{|c|c|c|c|c|}
\hline \multirow[b]{2}{*}{ Incentive } & \multirow[b]{2}{*}{ Initial Attitude } & \multicolumn{2}{|c|}{ Attitudes } & \multirow[b]{2}{*}{$\mathrm{t}$} \\
\hline & & $\begin{array}{c}\text { Recall vs } \\
\text { Initial }\end{array}$ & $\begin{array}{c}\text { Recall vs } \\
\text { Final }\end{array}$ & \\
\hline $\begin{array}{l}\$ 2.50 \\
\$ .50\end{array}$ & $\begin{array}{l}\text { Salient } \\
\text { Salient }\end{array}$ & $\begin{array}{l}.84 \\
.78\end{array}$ & $\begin{array}{l}.34 \\
.37\end{array}$ & $\begin{array}{l}2.16^{*} \\
1.59\end{array}$ \\
\hline $\begin{array}{l}\$ 2.50 \\
\$ .50\end{array}$ & $\begin{array}{l}\text { Misattributed } \\
\text { Misattributed }\end{array}$ & $\begin{array}{l}.42 \\
.26\end{array}$ & $\begin{array}{l}.81 \\
.92\end{array}$ & $\begin{array}{l}1.70 \\
2.98 \dagger\end{array}$ \\
\hline Control & & .80 & .65 & .79 \\
\hline
\end{tabular}

${ }^{*} p<.05 \quad$ fp $<.001$

$\mathrm{p}<.03$ ) established the incentive theory predicted positive relationship between incentive and attitude change when Ss wrote against salient initial attitudes, but the negative relationship predicted by dissonance theory was obtained when Ss wrote against misattributed initial attitudes.

Column 2 of Table 1 shows the average error within each treatment when Ss are asked to recall their initial attitudes. Control Ss and Ss in the two salient initial attitude conditions show very little error in recall, suggesting that accurate recollection of initial attitudes may be a parameter of incentive effects. For Ss in the $\$ 2.50$ payment, salient initial attitude condition, the contrast between attitude change and attitude recall is particularly evident, and these Ss may experience some attitude change. But for Ss who write against initially misattributed attitudes, error in the recall of their initial attitudes is seen to vary directly with the amount of attitude change. Hence, Ss who reproduce the dissonance predicted negative relationship between incentive and attitude change do not recall their initial attitudes, nor do they experience attitude change (Bem \& McConnell, 1970). The comparison of the errors in recall of initial attitudes between the two salient and two misattributed conditions was highly significant $(\mathrm{t}=3.11, \mathrm{df}=58, \mathrm{p}<.001)^{2}$

\section{Additional Analyses}

To examine the within-cells relationships between salience, incentive, and attitude change, product-moment correlations were computed between recall and initial attitudes and recall and final attitudes for each treatment (Table 2). As shown in Table 2, the within-cells correlations reiterate the finding that dissonance effects are obtained by misattribution of initial attitudes and that incentive effects follow from increasing the salience of the same initial attitudes. Ss who are paid $\$ 2.50$ to write against salient initial attitudes accurately recall their initial attitudes and show very little confounding of their final attitudes with measures of recall $(\mathrm{p}<.05)$. The same trend is also evident in the 50-cent payment, salient initial attitude condition but fails to attain significance. However, when Ss write against initial attitudes that are misattributed, 
measures of recall are quite similar to the final attitudes and largely unrelated to the initial attitudes, a nonsignificant trend in the $\$ 2.50$ payment condition that becomes highly significant $(p<.001)$ for the Ss who receive smaller incentives for writing against misattributed initial attitudes.

\section{DISCUSSION}

As noted in the introduction, the present study may be viewed as a single validation of the experimental findings reported by Bem and McConnell (1970) and the simulation data gathered by Jones et al (1968) and Piliavin et al (1969). Thus, while Jones et al and Piliavin et al interpreted their countersimulations as evidence counting against the self-perception theory, the finding that Ss who were provided information concerning initial attitudes reproduced positive relationships between incentives and attitude change, while the dissonance predicted negative relationship was obtained when the information was omitted, suggests that the salience of initial attitudes would differentiate the two predictions in a forced compliance experiment.

Although the salience or misattribution of initial attitude functions as one parameter mediating between the two predictions, it is important to emphasize that the Piliavin et al simulation data identify several additional variables, as yet unexplored, that may also differentiate between dissonance and incentive effects. Specifically, the extent to which Ss perceive payment as a cause of their counteradvocacy, the presence or absence of biased scanning, and the Ss' definitions of their role in the forced compliance paradigm might be varied in further studies of incentive and attitude change.

In addition to reemphasizing the utility of the self-perception theory and the simulation data for clarifying a specific dissonance phenomena, a more sociologically oriented interpretation would note that the experimental instructions and the behavior shown by the Ss in the salient initial attitude groups closely approximate the role of the Devil's advocate. Indeed, Ss with salient initial attitudes not only wrote essays against their perceptions of their private beliefs but they also recalied their initial attitudes and the discrepancy between these attitudes and their final attitudes. Hence, when Ss "perceive" attitude change in themselves, larger rather than smaller incentives appear to induce more attitude change.

Epstein's (1969) finding that high- and low-scoring Ss on the Machiavellianism Scale respond differently to emotional and rational appeals may implicate Machiavellianism as a personality variable that mediates the present findings. Epstein suggests that the role of counteradvocacy against a consciously held attitude characterizes Ss scoring high on the Machiavellianism Scale. If so, we might expect that a replication of the present study, controlled for Machiavellianism, would show the most attitude change for high Machiavellians writing against salient initial at titudes for large incentives and that Ss obtaining low scores on the Machiavellianism Scale would show most attitude change when writing against misattributed initial attitudes for small incentives. The hypothesized triple interaction between Machiavellianism, magnitude of incentive, and salience of initial attitude is also consistent with studies reported by Christie and Geis (1970) which show less attitude change for high Machiavellians in standardized dissonance paradigms that do not vary incentives.

In conclusion, the self-perception theory and the simulation data following from it may be extended to identify parameters of many diverse dissonance phenomena, and the recent and rapidly increasing interest in self-attribution processes may enable social psychologists to establish and replicate many additional findings in experimental settings.

\section{REFERENCES}

Bem, D. J. An experimental analy sis of self-persuasion. Journal of Experimental Social Psychology, 1965, 1, 199-218.

Bem, D. J. Self-perception: An alternative interpretation of cognitive dissonance phenomena. Psychological Review, 1967, 74, 183-200.

Bem, D. J. The epistemological status of interpersonal simulations: A reply to Jones, Linder, Kiesler, Zanna, \& Brehm. Journal of Experimental Social Psychology, 1968, 4 , 270-274.

Bem, D. J., \& McConnell, H. K. Testing the self-perception explanation of dissonance phenomena: On the salience of premanipulation attitudes. Journal of Personality \& Social Psycholozy, 1970, 14, 23-31.

Brehm, J. W., \& Cohen, A. R. Explorations in cognitive dissonance. New York: Wiley, 1962.

Carlsmith, J. M., Collins, B. E., \& Helmreich, R. L. Studies in forced compliance: I. The effect of pressure for compliance on attitude change produced by face-to-face role-playing and anonymous essay writing. Journal of Personality \& Social Psychology, 1966, 4, 1-13.

Christie, R. J., \& Geis, F. L. Studies in Machiavellianism. New York: Academic Press, 1970.

Cohen, A. R. In J. W. Brehm and A. R. Cohen (Eds.), Explorations in cognitive dissonance. New York: Wiley, 1962.

Collins, B. E., Ashmore, R. D., Hornbeck, F. W.. \& Whitney, R. E. Studies in forced compliance: $X I I I$ and $X V$. In search of a dissonance-producing forced-compliance paradigm. Representative Research in Social Psychology, 1970, 1, 11-23.

Collins, B. E., \& Helmreich, R. L. Studies in forced compliance: II. Contrasting mechanisms of attitude change produced by public-persuasive and private true essays. Journal of Social Psychology, 1970,81, 253-264.

Collins, B. E., \& Hoyt, M. F. Magnitude of inducement, consequences, and responsibility-choice: $A$ theoretical and empirical integration of the forced compliance literature. Unpublished paper, University of Wisconsin, 1972.

Crano, W. D., \& Messe, L. A. When does dissonance fail? The time dimension in attitude measurement. Journal of Personality, 1970, 38, 493-508.

Elms, A. C., \& Janis, I. L. Counter-norm attitudes induced by constant versus dissonant conditions of role-playing. Joumal of Experimental Research in Personality, 1965, 1, 50-60.

Epstein, G. F. Machiavelli and the devil's advocate. Journal of Personality \& Social Psychology, 1969, 11, 38-41.

Festinger, L. A theory of cognitive dissonance. Evanston, Ill: Row Peterson, 1957.

Festinger. L., \& Carlsmith, J. M. Cognitive consequences of forced compliance. Journal of Abnormal \& Social Psychology, $1969,58,203-210$.

Helmreich, R. L., \& Collins, B. E. Studies in forced compliance: IV. Commitment and magnitude of inducement to comply as determinants of opinion change. Journal of Personality and Social Psychology, 1968, 10, 75-81.

Janis, I. L., \& Gilmore, J. B. The influence of incentive conditions on the success of role-playing in modifying attitudes. Journal of Personality \& Social Psychology, 1965, 
Jones, R. A., Linder, D. E., Kiesler, C. A., Zanna, M., \& Brehm, J. W. Internal states or external stimuli: Observers' attitude judgments and the dissonance self-perception controversy. Journal of Experimental Social Psychology, 1968, 4, 247-269.

Linder, D. E., Cooper, J., \& Jones, E. E. Decision freedom as a determinant of the role of incentive magnitude in attitude change. Journal of Personality \& Social Psychology, 1967, 6, 245-254.

Nel, E., Helmreich, R. L., \& Aronson, E. Opinion change in the advocate as a function of the persuasibility of his audience: $A$ clarification of the meaning of dissonance. Journal of Personality \& Social Psychology, 1969, 12, 117-124.

Pilia vin, J. A., Piliavin, I. M., Loewenton, E. P., McCauley, C., \& Hammond, P. On observers' reproductions of dissonance effects: The right answers for the wrong reasons? Journal of Personality \& Social Psychology, 1969, 13, 98-106.

Rosenberg, M. J. When dissonance fails: On eliminatin evaluation apprehension from attitude measurement. Journal of Personality \& Social Psychology, 1965, 1, 28-42.

Rossomando, N. P., \& Weiss, W. Attitude change, effects of timing, and amount of payment for counterattitudinal behavior. Journal of Personality \& Social Psychology, 1970 14, 32-38

Sherman, S. J. Effects of choice and incentive on attitude change in a discrepant behavior situation. Journal of Personality \& Social Psychology, 1970, 15, 245-252.

\section{NOTES}

1. Data were discarded for one $S$ who wrote a "pro-open visitation" essay. Running experimental sessions with fewer Ss per group, as in the present study, appears to minimize the rate of noncompliance.

2. Probabilities for all $t$ tests are two-tailed.

(Received for publication June 11,1973 revision received December 10,1973 .) 